\title{
Understanding the Sustainability of Fuel from the Viewpoint of Exergy
}

\author{
Yaning Zhang ${ }^{1,2^{*}}$, Wenke Zhao ${ }^{1}$, Bingxi Li ${ }^{1 *}$, Hongtao Li ${ }^{3}$ \\ 1 School of Energy Science and Engineering, Harbin Institute of Technology, Harbin, CHINA \\ ${ }^{2}$ Department of Bioproducts and Biosystems Engineering, University of Minnesota, St. Paul, USA \\ ${ }_{3}^{3}$ School of Mechanical Engineering, Hebei University of Science and Technology, Shijiazhuang, CHINA
}

*Corresponding Authors: ynzhang@hit.edu.cn (Yaning Zhang) and libx@hit.edu.cn (Bingxi Li)

Citation: Zhang, Y., Zhao, W., Li, B. and Li, H. (2018). Understanding the Sustainability of Fuel from the Viewpoint of Exergy. European Journal of Sustainable Development Research, 2(1), 09. https://doi.org/10.20897/ejosdr/76935

Published: January 30, 2018

\begin{abstract}
At the same time of providing a huge amount of energy to the world population (social sustainability) and global economy (economic sustainability), the fuel itself also releases a great amount of emissions to the environment the world people live in in the forms of gaseous pollutants $\left(\mathrm{SO}_{x}, \mathrm{NO}_{x}, \mathrm{CO}, \mathrm{CO}_{2}, \mathrm{CH}_{4}\right.$, etc.) and ash compositions $\left(\mathrm{Al}_{2} \mathrm{O}_{3}, \mathrm{CaO}, \mathrm{Fe}_{2} \mathrm{O}_{3}, \mathrm{~K}_{2} \mathrm{O}, \mathrm{MgO}, \mathrm{MnO}, \mathrm{Na}_{2} \mathrm{O}, \mathrm{P}_{2} \mathrm{O}_{5}, \mathrm{SO}_{3}, \mathrm{SiO}_{2}\right.$, TiO 2 , etc.), seriously impacting the environment (environmental sustainability) for the world population and global economy. Sustainability generally encompasses economic sustainability, environmental sustainability, and social sustainability, and all of these are significantly related to the energy/resource sustainability. This study addresses the sustainability of fuel from the viewpoint of exergy. It is demonstrated that the energy of a fuel is best evaluated by its chemical exergy, and the environmental impact of a fuel can be assessed through the chemical exergy of its emissions (the specific impacts such as toxicity or greenhouse effect are not detailed). Then, the sustainability of fuel can be understood from the viewpoint of exergy through three ways: (a) high chemical exergy of the fuel, (b) high exergy efficiency of the fuel conversion process, and (c) low chemical exergy of the emissions.
\end{abstract}

Keywords: sustainability, fuel, exergy, energy, environmental impact

\section{INTRODUCTION}

The world population and global economy are increasing and increasing, requiring more and more energy resources to support. These requirements include fossil fuel (coal, oil, natural gas, etc.), nuclear fuel (uranium dioxide, molten plutonium, uranium nitride, etc.), and renewable resources (biomass, hydropower, solar energy, geothermal energy, wind power, wave power, tidal power, etc.).

At the same time of providing a huge amount of energy to the world population and global economy, the energy resources themselves also release a great amount of emissions to the environment the world people live in. These emissions may include gaseous pollutants (e. g. $\mathrm{SO}_{x}, \mathrm{NO}_{x}, \mathrm{CO}, \mathrm{CO}_{2}, \mathrm{CH}_{4}$, etc.) and ash compositions (e. g. $\mathrm{Al}_{2} \mathrm{O}_{3}, \mathrm{CaO}, \mathrm{Fe}_{2} \mathrm{O}_{3}, \mathrm{~K}_{2} \mathrm{O}, \mathrm{MgO}, \mathrm{MnO}, \mathrm{Na}_{2} \mathrm{O}, \mathrm{P}_{2} \mathrm{O}_{5}, \mathrm{SO}_{3}, \mathrm{SiO}_{2}, \mathrm{TiO}_{2}$, etc.). These emissions would cause some effects on the environment. For example, the released $\mathrm{CO}_{2}$ would absorb infrared rays from the sun and result in greenhouse effects, which would cause global warming and melt glaciers. The released $\mathrm{NO}_{2}$ and $\mathrm{SO}_{2}$ would react with water in air and form acid rain, which would kill the plants and fish on the earth. The emitted ash would become very small particles and fly into air, which would impair the lungs of people and pollute the water in rivers. These impacts seriously deteriorate the environment for the world population and in return they cause heavy 
burden on the global economy. Sustainability is therefore becoming more and more concerned, especially when the haze in China becomes heavier and heavier and the global environment becomes worse and worse.

Exergy is an important tool for measuring the maximum amount of obtainable work (Szargut, 1980; Rosen and Dincer, 1997; Dincer, 2002; Rosen, 2009a), it has been widely used to evaluate the energy qualities of natural resources (Wall et al., 1994; Chen et al., 2006; Chen and Chen, 2007; Dai and Chen, 2010). With extensions, exergy is also developed to study labor (Sciubba, 2001; Jahangir et al., 2016), population (Sciubba and Zullo, 2013), capital (Sciubba, 2001; Rosen and Dincer, 2003; Sciubba, 2003; Colombo et al., 2015), and ecology (Ukidwe and Bakshi, 2007; Jiang and Chen, 2011; Chen et al., 2014; Dai et al., 2014).

Some researchers ever addressed/studied sustainability (sustainable development) from the viewpoint of exergy. Rosen and Dincer (2001) proposed that exergy can be used as the confluence of energy, environment, and sustainable development. Wall and Gong (2001) recommended using stored exergy as an ecological indicator for sustainable development. Sciubba and Zullo (2011) adopted thermodynamic function exergy to correlate sustainability and thermodynamics. Koroneos et al. (2012) developed an exergy indicator for measuring sustainability through establishing a relationship between exergy content and environmental impact of energy resources. Dincer and Rosen (2005) studied the relationship between exergy and sustainability of a process. Stougie and van der Kooi (2012) studied exergy and sustainability by addressing exergy loss as a qualitative measure of environmental effects. Wu et al. (2015) used cosmic exergy to assess the sustainability of biogas systems. Chen et al. used extended-exergy analysis to study the sustainability of Chinese societal system (Chen and Chen, 2009) and Chinese biogas project (Yang and Chen, 2014). Dincer and Naterer (2010) studied the sustainability index (SI) of an air-water heat pump through assessing exergy efficiency. Caliskan (2014) studied the sustainability index of a building heating system with a combi-boiler based on exergy efficiency. Whiting et al. (2017) evaluated the sustainability of fossil fuels through focusing on the exergy replacement cost methodology. Generally, these studies mainly concentrated on the energy resources, environment problems, or exergy efficiency.

Fuel (e. g. coal, oil, natural gas, biomass, etc.) is a very important energy resource, and it is quite different from the other energy resources like hydropower, solar energy, geothermal energy, wind power, wave power, and tidal power which mainly supply energy to the society whereas release no pollutants to the environment. Fuel, on the other hand, not only supplies energy to the society but also releases emissions to the environment. A comprehensive understanding of the sustainability of fuel from the viewpoint of exergy is still needed.

\section{SUSTAINABILITY AND FUEL}

\section{Statement for Sustainability}

There are various statements for sustainability or sustainable development. Some of the statements are presented in this section.

The IUCN (International Union for the Conservation of Nature and Natural Resources) statement presented in the World Conservation Strategy (WCS) in 1980 (IUCN, 1980): the overall aim of achieving sustainable development through the conservation of living resources.

The WCED (World Commission on Environment and Development) statement or Brundtland Commission Report in 1987 (WCED, 1987): sustainable development is development that meets the needs of the present without compromising the ability of future generations to meet their own needs.

The statement presented in the Encyclopedia of Life Support Systems (EOLSS, 2002): the wise use of resources through critical attention to policy, social, economic, technological, and ecological management of natural and human engineered capital so as to promote innovations that assure a higher degree of human needs fulfillment, or life support, across all regions of the world, while at the same time ensuring intergenerational equity.

The statement adopted by Wikipedia, the free encyclopedia (Wikipedia, 2017): sustainability is the endurance of systems and processes.

Among the various statements, the WCED statement (also Brundtland Commission Report) is the most popular and often cited definition. The popularity is validated by the World Bank, the World Resources Institute, the World Wildlife Fund, the Worldwatch Institute, the Global Tomorrow Coalition, the International Institute for Environment and Development, the US Agency for International Development, the Canadian and Swedish International Development Agencies, etc. On November 18, 1992, the Rio de Janeiro (Brazil) conference gave the WCED statement a global mission status through the UN Conference on Environment and Development (UNCED).

Even for the same WCED statement (Brundtland Commission Report), there are numerous understandings and interpretations. Up to now, 169 targets, 17 goals, and 304 indicators have been proposed to lead, evaluate, or measure sustainability (Wikipedia, 2017). Generally, sustainability encompasses several perspectives or pillars. Most of the scholars prefer that sustainability is a triangle of economic sustainability, environmental sustainability, and 


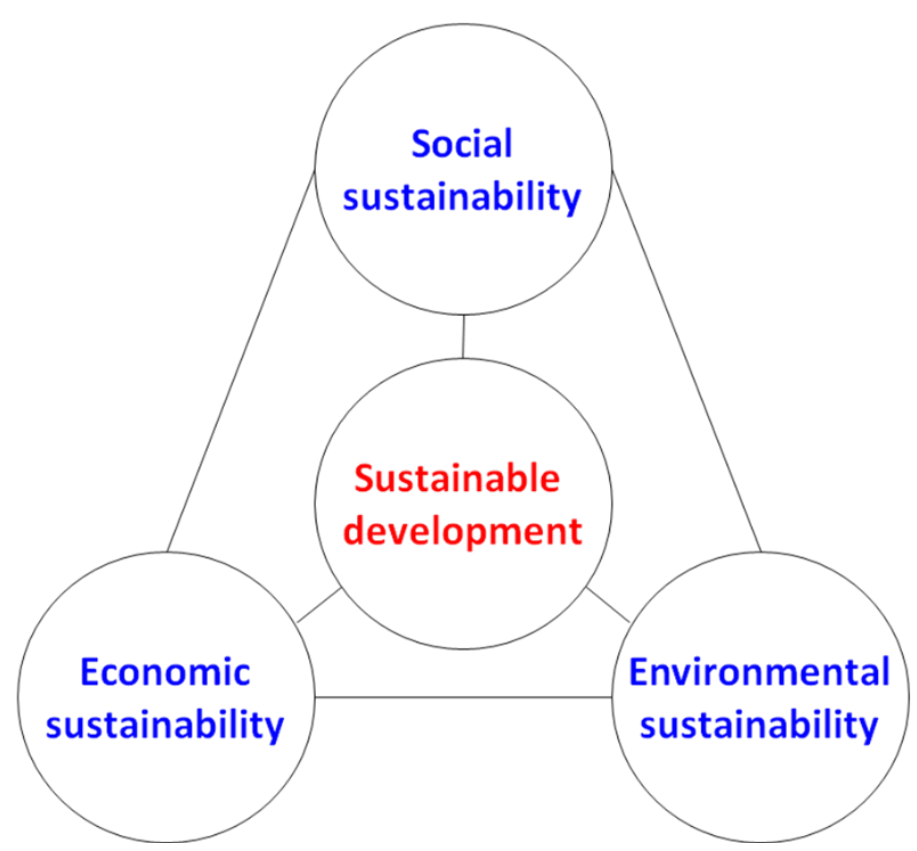

Figure 1. Sustainability triangle (Rosen, 2009b; Romero and Linares, 2014; Bilgen and Sarkkaya, 2015; Rosen, 2017a)

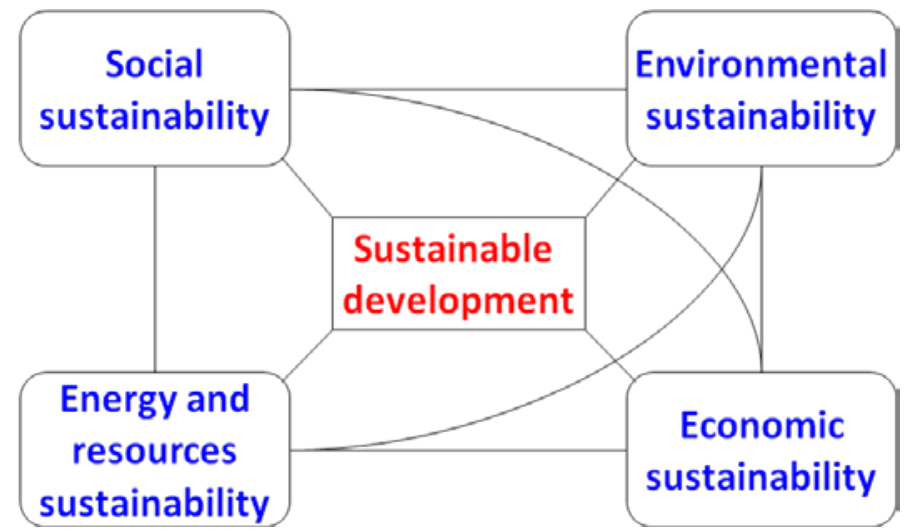

Figure 2. Four key factors involved in sustainable development (Dincer and Rosen, 2005)

social sustainability which is shown in Figure 1 (Rosen, 2009b; Romero and Linares, 2014; Bilgen and Sarikaya, 2015; Rosen, 2017 a). Dincer and Rosen (2005) furthered to state that sustainable development involves four key factors: environmental sustainability, economic sustainability, social sustainability, and resource/energy sustainability (Figure 2). Rosen (2017b) furthered to state that sustainable development is a multidisciplinary concept involving environment, ecology, sociology, economy, science, and engineering. Generally, sustainable development involves economic sustainability, social sustainability, and environmental sustainability, and all of them link to energy and resources sustainability, since all of these are strongly interlinked (Dincer and Rosen, 2005; Romero and Linares, 2014) and energy/resource sustainability is of great importance to the overall sustainability (Rosen, 2009b). Energy/resource sustainability is therefore focused on in the following sections.

\section{Sustainability and Fuel}

World population (social sustainability) and global economy (economic sustainability) are dependent on energy. Figure 3 shows the world population, global GDP, and world energy consumption during the years of 2006-2015. As the world population increased monotonically in the range of $6.52-7.35$ billion with an increase rate of $12.73 \%$ (FAO, 2017) and the global GDP (gross domestic product) fluctuated in the range of 51.04-77.83 trillion U.S. dollars with an increase rate of 52.49\% during the years of 2006-2015 (The World Bank, 2017; Statista, 2017), the world primary energy consumption nearly increased monotonically in the range of 11.27-13.15 $\times 10^{3}$ Mtoe (million tonnes oil equivalent) with an increase rate of $16.68 \%$ during the same period (Statistical Review of World Energy, 2017). This means that social sustainability and economic sustainability are significantly dependent on energy sustainability.

Figure 4 shows the world energy production of fossil fuels (coal, oil, and natural gas) during the years of 20062015 (Statistical Review of World Energy, 2017). The world production of fossil fuels nearly increased monotonically in the range of $9.76-11.39 \times 10^{3}$ Mtoe with an increase rate of $16.70 \%$. These were $85.68 \%-87.81 \%$ 


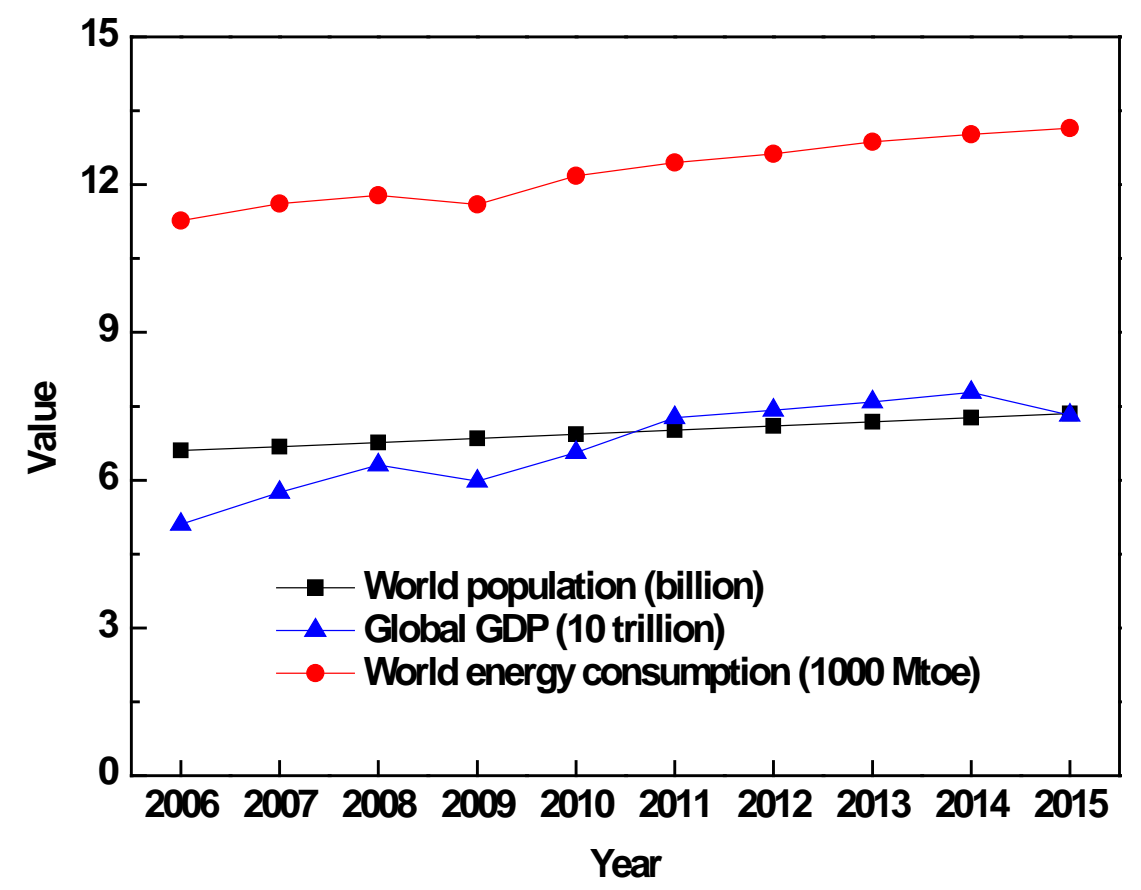

Figure 3. World population, global GDP, and world energy consumption during 2006-2015 (FAO, 2017; The World Bank, 2017; Statista, 2017; Statistical Review of World Energy, 2017)

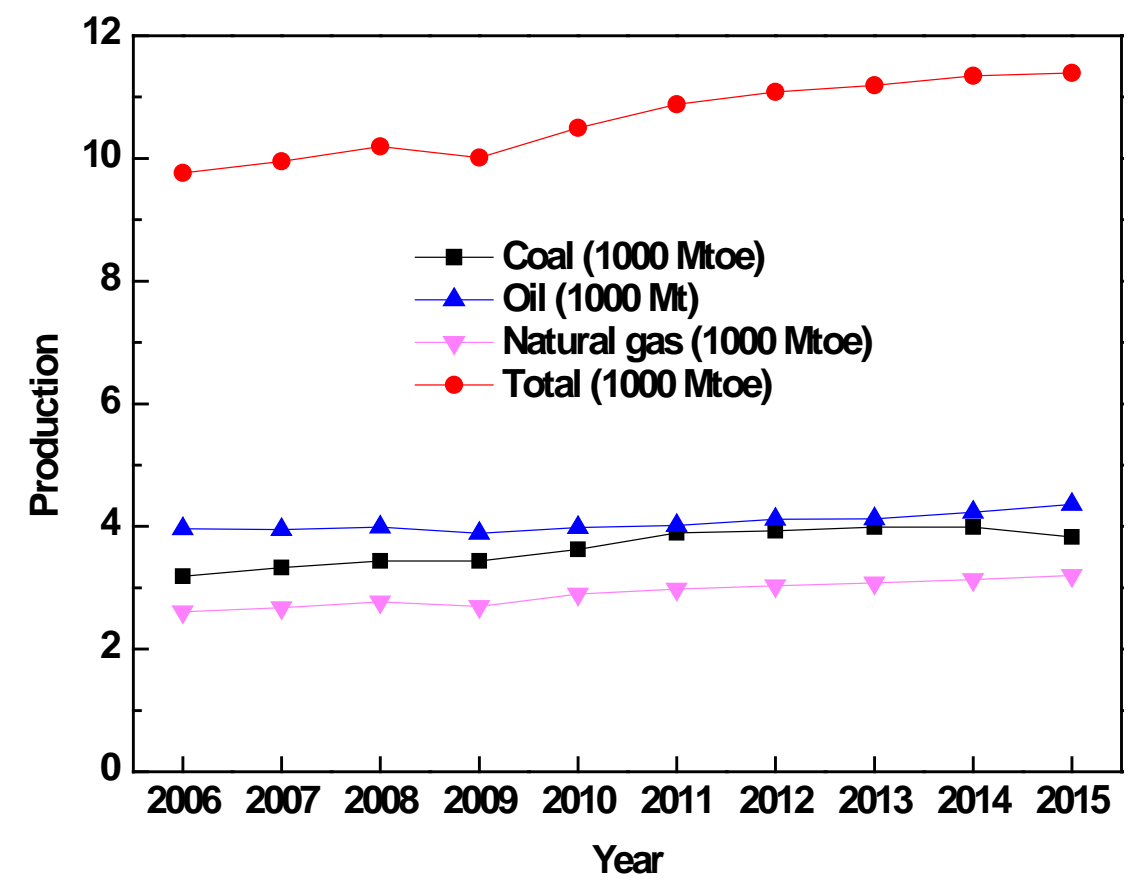

Figure 4. World energy production during 2006-2015 (Statistical Review of World Energy, 2017)

of world primary energy consumption (11.27-13.15 $\times 10^{3}$ Mtoe), indicating that the fossil fuels contributed significantly to the world primary energy consumption. Specifically, the world energy production of fossil fuels was contributed by coal, oil, and natural gas which varied in the ranges of 3.19-3.83 $\times 10^{3}$ Mtoe, 3.96-4.36 $\times 10^{3}$ Mt, and 2.61-3.20 $\times 10^{3}$ Mtoe with increase rates of 20.06\%, 10.10\%, and 22.61\% during the years of 2006-2015, respectively.

The above data collectively indicate that social sustainability and economic sustainability are significantly dependent on energy/fuel sustainability. When we talk about sustainable development, sustainable energy/fuel resources should be available, and they should be efficiently used (Rosen, 2002; Dincer and Rosen, 2005; Kanoglu et al., 2009; Bilgen and Sarkaya, 2015). 


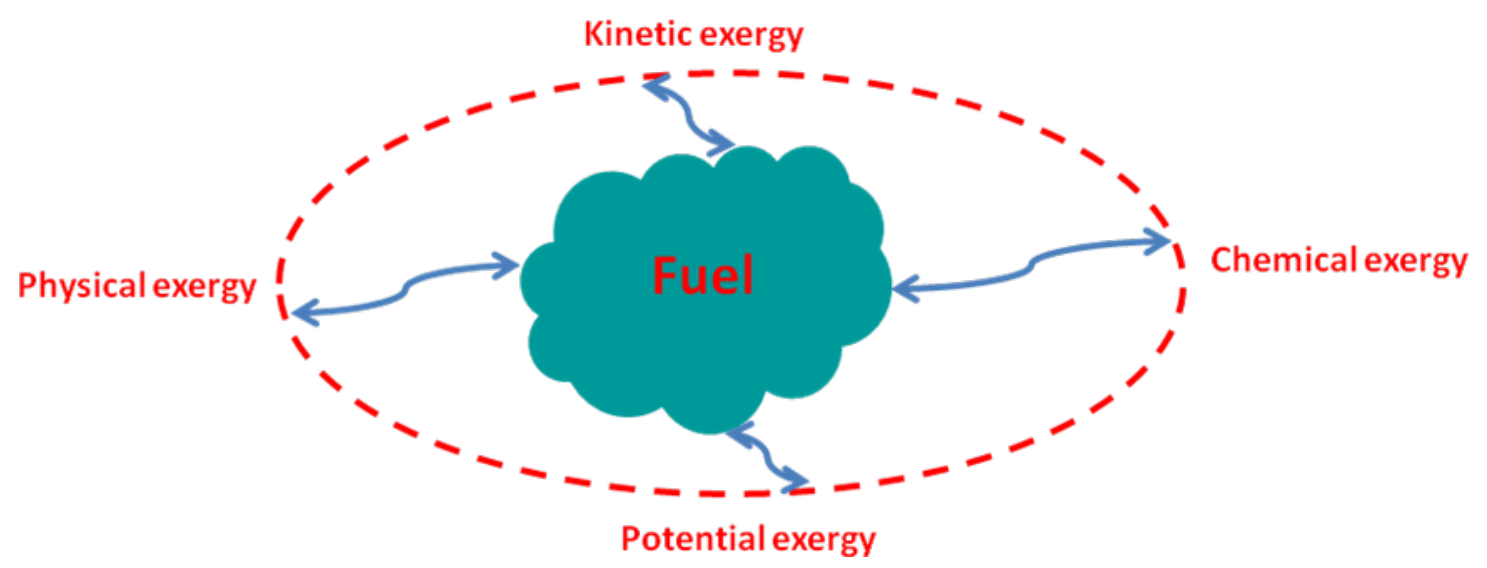

Figure 5. Four forms of exergy for a fuel

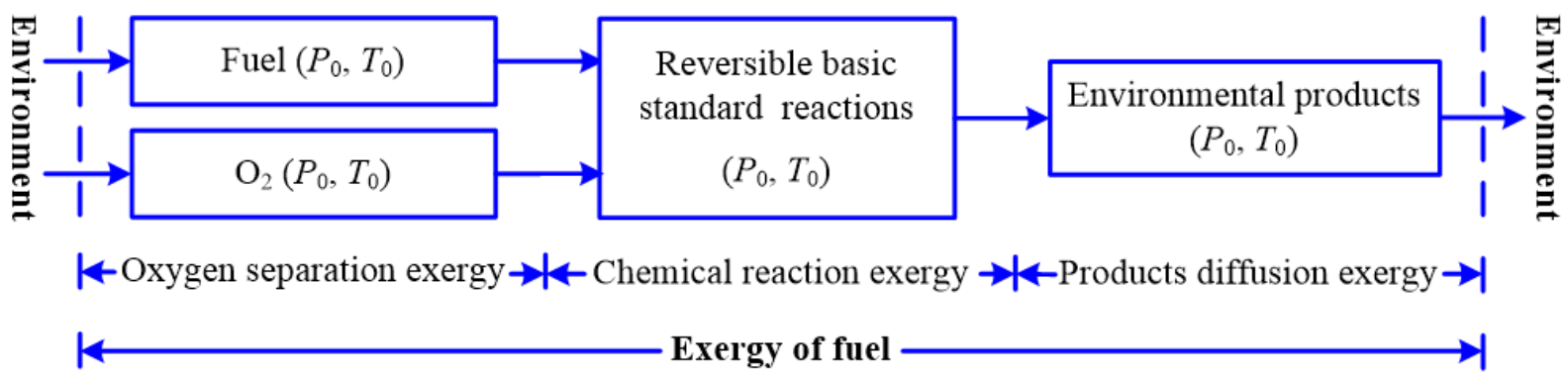

Figure 6. A comprehensive thermodynamic model for the (chemical) exergy of fuel

\section{ENERGY FROM FUEL THROUGH EXERGY}

\section{Statement for Exergy}

There are some modern statements for exergy. Szargut et al. (1988) defined: exergy is the amount of work obtainable when some matter is brought to a state of thermodynamic equilibrium with the common components of natural surroundings by means of reversible processes, involving interactions only with the above mentioned components of nature. They also defined: exergy is the shaft work or electrical energy necessary to produce a material in its specified state from materials common in the environment in a reversible way, heat being exchanged only with the environment at temperature $T_{0}$.

Similarly, Sciubba and Wall (2004) defined exergy as: the maximum theoretical useful work obtained if a system ' $\mathrm{S}$ ' is brought into thermodynamic equilibrium with the environment by means of processes in which ' $\mathrm{S}$ ' interacts only with this environment.

According to the above statements, the exergy of an energy/fuel resource is the amount of maximum obtainable work when the energy/fuel resource is brought to a state of thermodynamic equilibrium with the common components of natural surroundings (environmental condition) by means of reversible processes, involving interactions only with the components (mentioned above) of natural surroundings (Rosen and Dincer, 1997; Rosen, 2002; Dincer and Rosen, 2005; Rosen et al., 2008). It measures not only how far the energy/fuel resource deviates from the state of equilibrium with its environment (Wall, 1986), but also measures the quality of the energy/fuel resource (Zhang et al., 2013; Zhang et al., 2015a; Zhang et al., 2016a). Therefore, exergy is widely used to evaluate the energy quality of an energy/fuel resource.

\section{Exergy of Fuel}

Generally, there are four forms of exergy for a fuel material: kinetic exergy, potential exergy, physical exergy, and chemical exergy (Figure 5). The kinetic exergy is associated with relative motion difference between the material and its surroundings. The potential exergy is associated with the gravitational or electromagnetic difference. The physical exergy is from differences in the pressures and temperatures, and the chemical exergy is from differences in the components and concentrations (Szargut, 2005). Since the kinetic exergy and potential exergy generally account for less than $0.001 \%$ of the total exergy of a material, they can therefore be neglected (Zhang et al., 2015b). The physical exergy of a material attributed by pressure and temperature differences is usually also neglected because the material in environmental condition is in equilibrium with the pressure and temperature 


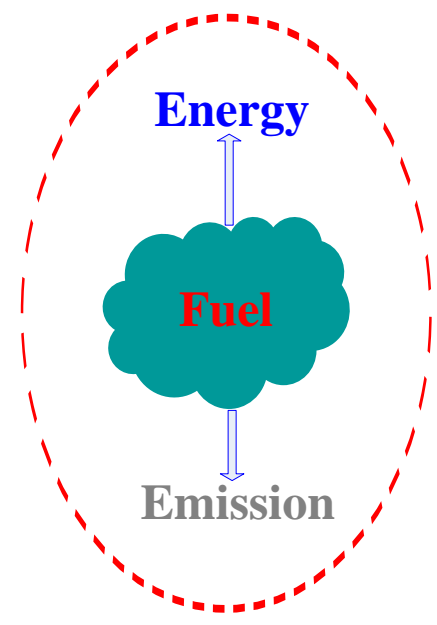

Figure 7. Energy release process of fuel

Table 1. Emission inventories for some common types of fuels (Liu and Li, 2015)

\begin{tabular}{lccccc}
\hline Fuel & SO $\boldsymbol{x}$ & $\mathbf{N O}$ & $\mathbf{C O}$ & $\mathbf{C O}_{2}$ & $\mathbf{C H}_{4}$ \\
\hline Coal $(\mathrm{g} / \mathrm{kg})$ & 0.007 & 0.043 & 0.005 & 6.2 & 9.320 \\
\hline Crude oil $(\mathrm{g} / \mathrm{kg})$ & 0.206 & 0.200 & 0.008 & 80.4 & 0.786 \\
\hline LPG $(\mathrm{g} / \mathrm{kg})$ & 1.360 & 0.988 & 0.157 & 260.0 & 0.253 \\
\hline Fuel oil $(\mathrm{g} / \mathrm{kg})$ & 1.130 & 0.823 & 0.131 & 210.0 & 0.211 \\
\hline Natural gas $\left(\mathrm{g} / \mathrm{m}^{3}\right)$ & 0.191 & 0.187 & 0.007 & 74.8 & 0.007 \\
\hline
\end{tabular}

of the environment. The chemical exergy of a fuel, therefore, appears to be a more representative index than the total exergy of the fuel (Rosen and Dincer, 1999; Crane et al., 1992).

According to the general definition of exergy, the (chemical) exergy of a fuel can be calculated from a multiprocess thermodynamic model which is also a comprehensive thermodynamic model (Figure 6). The multiprocess thermodynamic model includes three sub-process models: (a) the oxygen separation process, (b) the chemical reaction process, and (c) the products diffusion process. The oxygen separation process means oxygen $\left(\mathrm{O}_{2}\right)$ is separated from the environment at the environmental sate $\left(P_{0}, T_{0}\right)$, and the exergy involved is oxygen separation exergy. The chemical reaction process requires the fuel reacts with oxygen at the environmental sate $\left(P_{0}, T_{0}\right)$, and the products are the environmental products which are the environmental compositions. The exergy involved in this process is called chemical reaction exergy. The products diffusion process means the environmental products diffuse to the environment and get equilibrium with the environment at the environmental sate $\left(P_{0}, T_{0}\right)$. The exergy involved in this process is defined as products diffusion exergy. The (chemical) exergy of a fuel is then the sum of the oxygen separation exergy, chemical reaction exergy, and products diffusion exergy.

This multi-process thermodynamic model would yield accurate results whereas the calculation process is a little complex. Recently, many authors dedicated to working on the estimation of exergy for fuels. The related work can be accessed everywhere (Szargut et al., 1988; Szargut, 2005; Zhang et al., 2016b; Li et al., 2017).

\section{ENVIRONMENTAL IMPACT FROM FUEL THROUGH EXERGY}

\section{Emissions from Fuel}

At the same time of providing a huge amount of energy to the social sustainability and economic sustainability, the fuel itself also releases a great amount of emissions to the environment the world people live in. The energy contained in a fuel is mainly its chemical energy, and this energy can be obtained when the fuel is combusted (usually through combustion). This process can be illustrated by Figure 7 .

Table 1 shows the emission inventories for some common types of fuels (coal, crude oil, LPG (liquefied petroleum gas), fuel oil, and natural gas). Even for the easily combustible natural gas, $\mathrm{SO}_{x}, \mathrm{NO}_{x}, \mathrm{CO}_{2} \mathrm{CO}_{2}$, and $\mathrm{CH}_{4}$ may be released when the natural gas is combusted. Usually, these emissions may cause some environmental impacts on the environment, e. g. greenhouse effect, stratospheric ozone depletion, acid precipitation and photochemical smog as shown in Table 2 (Dincer, 2000).

If an ash containing fuel (usually solid fuels like coal and biomass) is used or combusted, the process would release not only gaseous pollutants $\left(\mathrm{SO}_{x}, \mathrm{NO}_{x}, \mathrm{CO}, \mathrm{CO}_{2}, \mathrm{CH}_{4}\right.$, etc.) but also ash compositions $\left(\mathrm{Al}_{2} \mathrm{O}_{3}, \mathrm{CaO}_{2} \mathrm{Fe}_{2} \mathrm{O}_{3}\right.$, $\mathrm{K}_{2} \mathrm{O}, \mathrm{MgO}, \mathrm{MnO}, \mathrm{Na}_{2} \mathrm{O}, \mathrm{P}_{2} \mathrm{O}_{5}, \mathrm{SO}_{3}, \mathrm{SiO}_{2}, \mathrm{TiO}_{2}$, etc.). This general process can be illustrated by Figure 8. 
Table 2. Gaseous pollutants and their impacts on the environment (Dincer, 2000)

\begin{tabular}{|c|c|c|c|c|}
\hline Gaseous pollutant & Greenhouse effect & Ozone depletion & Acid precipitation & Photochemical smog \\
\hline \multicolumn{5}{|l|}{ Carbon monoxide (CO) } \\
\hline Carbon dioxide $\left(\mathrm{CO}_{2}\right)$ & + & \pm & & \\
\hline Methane $\left(\mathrm{CH}_{4}\right)$ & + & \pm & & \\
\hline Nitric oxide $(\mathrm{NO})$ and nitrogen dioxide $\left(\mathrm{NO}_{2}\right)$ & & \pm & + & + \\
\hline Nitrous oxide $\left(\mathrm{N}_{2} \mathrm{O}\right)$ & + & \pm & & \\
\hline Sulfur dioxide $\left(\mathrm{SO}_{2}\right)$ & - & + & & \\
\hline
\end{tabular}

+ stands for positive contribution, and - stands for variation with conditions and chemistry, may not be a general contributor.

\section{Gas: $\mathrm{CO}_{2}, \mathrm{NO}_{x}, \ldots$}

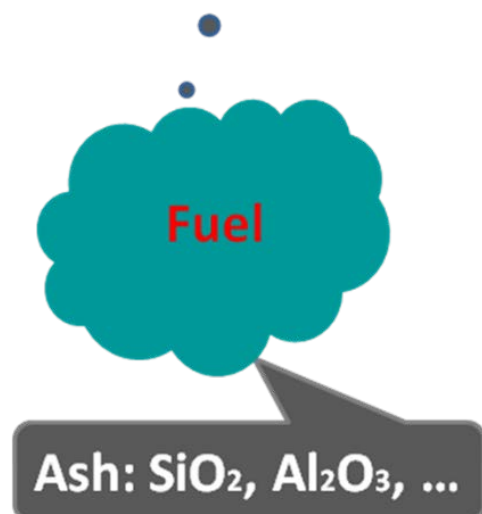

Figure 8. Emissions from fuel

\section{Environmental Impact of Emissions}

There are numerous methodologies that adopted for assessing the environmental impact of emissions, e. g. Life Cycle Assessment (LCA), Environmental Impact Assessment (EIA), Greenhouse Gas (GHG) methodology, etc. Compared with the Life Cycle Assessment (LCA) and Environmental Impact Assessment (EIA) methodologies which refer to the specific conditions in specific production plants (Jegannathan and Nielsen, 2013) and therefore would be significantly affected (Atilgan and Azapagic, 2015), the Greenhouse Gas (GHG) methodology is indicated as carbon footprint and it is much more intuitive and simpler.

Although the Greenhouse Gas (GHG) methodology can be easily used to assess the environmental impact of a fuel by demonstrating the greenhouse gas emissions of $\mathrm{CO}_{2}$ and $\mathrm{CH}_{4}$, the other environmental emissions (e. g. $\mathrm{NO} x, \mathrm{SO}_{2}$, and ash) are not included (Zhang et al., 2017). On the other hand, the Greenhouse Gas (GHG) methodology lacks a uniform reference basis for assessing the environmental impacts of different emissions and it therefore shows difficulties in comparing the environmental impacts of different fuels. For example, if a coal generates a total emission of $1.1 \mathrm{~kg}$ of $\mathrm{CO}_{2}$ and a biofuel generates a total emission of $0.9 \mathrm{~kg}$ of $\mathrm{SO}_{2}$, how can we compare the environmental impacts of these two fuels?

Exergy is the amount of work obtainable when a matter is brought to a state of thermodynamic equilibrium with the uniform environment reference (Szargut, 1980; Rosen and Dincer, 1997; Dincer, 2002; Rosen, 2009b), and it is an effective measure of the potential the matter impacts or changes the environment (Dincer and Rosen, 1998; Utlu and Hepbasli, 2004; Dincer, 2007; Koroneos and Tsarouhis, 2012). Therefore, some researchers suggested that the environmental impacts of emissions are best addressed by considering exergy (Rosen and Dincer, 1997; Dincer, 2000; Midilli and Dincer, 2010; Caliskan, 2015).

Since the kinetic exergy and potential exergy account for less than $0.001 \%$ of the total exergy of the emissions, they can therefore be neglected (Zhang et al., 2015 b). The physical exergy of an emission attributed by pressure and temperature differences is usually not significant and its potential environmental impact is limited as the pressure difference between the emission and the environment normally dissipates shortly after the emission enters the environment, and the temperature difference is normally localized near the emission source (Rosen and Dincer, 1999; Ao et al., 2008, Crane et al., 1992). The chemical exergy of emissions, therefore, appears to be a more representative index than their total exergy (Rosen and Dincer, 1999; Crane et al., 1992; Kirova-Yordanova, 2010).

Based on the emissions released from a fuel, the environmental impact of the fuel can be obtained by (Zhang et al., 2017): 
Table 3. Chemical exergy of emission gases and ash compositions (Szargut et al., 1988)

\begin{tabular}{lc}
\hline Material & Standard chemical exergy (kJ/mol) \\
\hline Emission gases & 275.10 \\
\hline $\mathrm{CO}$ & 19.87 \\
\hline $\mathrm{CO}_{2}$ & 106.90 \\
\hline $\mathrm{N}_{2} \mathrm{O}$ & 88.90 \\
\hline $\mathrm{NO}$ & 55.60 \\
\hline $\mathrm{NO}_{2}$ & 313.40 \\
\hline $\mathrm{SO}_{2}$ & 7.90 \\
\hline $\mathrm{Ash}$ compositions & 413.10 \\
\hline $\mathrm{SiO}_{2}$ & 110.20 \\
\hline $\mathrm{K}_{2} \mathrm{O}$ & 412.65 \\
\hline $\mathrm{CaO}$ & 66.80 \\
\hline $\mathrm{P}_{2} \mathrm{O}_{5}$ & 200.40 \\
\hline $\mathrm{MgO}_{\mathrm{Al}}$ & 16.50 \\
\hline $\mathrm{Al}_{2} \mathrm{O}_{3}$ & 296.20 \\
\hline $\mathrm{Fe}_{2} \mathrm{O}_{3}$ & 249.10 \\
\hline $\mathrm{Na}_{2} \mathrm{O}$ &
\end{tabular}

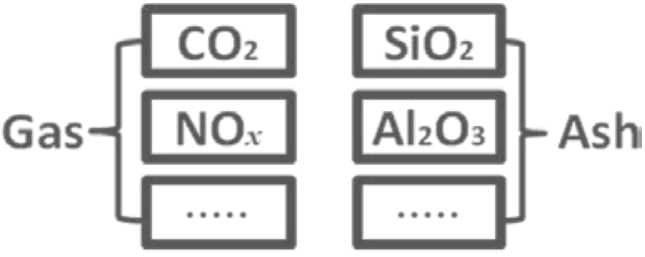

\section{Universal Exergy Base}

Figure 9. Universal basis for emissions

$$
P E I=P E I_{\mathrm{Gas}}+P E I_{\mathrm{Ash}}
$$

where:

PEI is the total environmental impact of a fuel $(\mathrm{kJ} / \mathrm{kg})$

$P E I_{\mathrm{Gas}} \quad$ is the environmental impact of the emission gases $(\mathrm{kJ} / \mathrm{kg})$

$P E I_{\text {Ash }} \quad$ is the environmental impact of the ash $(\mathrm{kJ} / \mathrm{kg})$

The environmental impact of emission gases, $P E I_{\text {Gas }}$, is given by (Zhang et al., 2017):

$$
P E I_{\mathrm{Gas}}=\sum m_{i} e x_{i}
$$

where:

$i \quad$ indicates the emission gases

$m_{i} \quad$ is the production of emission gas $i(\mathrm{~mol} / \mathrm{kg})$

$e x_{i} \quad$ is the standard chemical exergy of emission gas $i$ as shown in Table $3(\mathrm{~kJ} / \mathrm{mol})$

The environmental impact of ash, $P E I_{\text {Ash }}$, is given by (Zhang et al., 2017):

$$
P E I_{\mathrm{Ash}}=\sum m_{j} e x_{j}
$$

where:

$j \quad$ indicates the ash components

$m_{j} \quad$ is the mass of ash component $(\mathrm{mol} / \mathrm{kg})$

$e x_{j} \quad$ is the standard chemical exergy of ash component $j$ as shown in Table $3(\mathrm{~kJ} / \mathrm{mol})$

As exergy is defined on a global uniform environment reference basis, the environmental impact of an emission demonstrated by its chemical exergy is therefore also on a universal basis (Figure 9). The methodology presented above overcomes the problem with the Greenhouse Gas (GHG) methodology which lacks a uniform reference basis and it therefore has difficulties in comparing the environmental impacts of different emissions. On the contrary, the methodology presented above can be easily used to assess the environmental impacts of different emissions including gaseous pollutants $\left(\mathrm{SO}_{x}, \mathrm{NO}_{x}, \mathrm{CO}, \mathrm{CO}_{2}, \mathrm{CH}_{4}\right.$, etc.) and ash compositions $\left(\mathrm{Al}_{2} \mathrm{O}_{3}, \mathrm{CaO}_{2} \mathrm{Fe}_{2} \mathrm{O}_{3}\right.$, $\mathrm{K}_{2} \mathrm{O}, \mathrm{MgO}, \mathrm{MnO}, \mathrm{Na}_{2} \mathrm{O}, \mathrm{P}_{2} \mathrm{O}_{5}, \mathrm{SO}_{3}, \mathrm{SiO}_{2}, \mathrm{TiO}_{2}$, etc.). However, the universal exergy method also has some limits, e. g. it doesn't refer to the toxicity or greenhouse effect of an emission. 


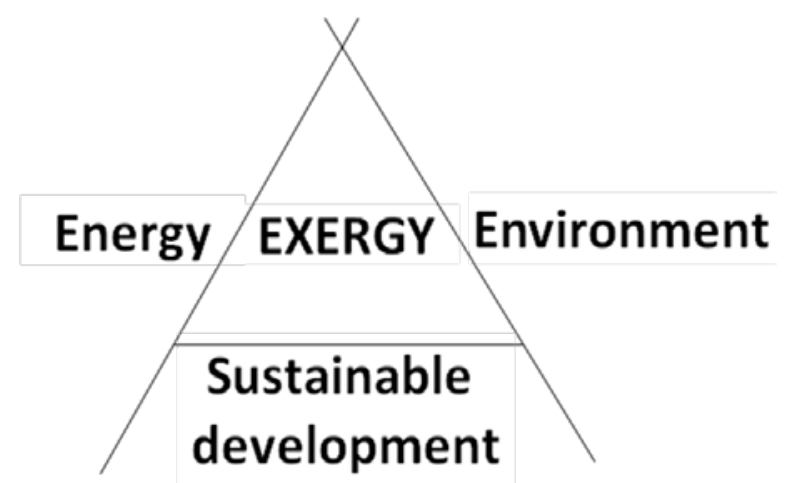

Figure 10. Interdisciplinary triangle covered by exergy (Rosen and Dincer, 2001; Dincer, 2002)

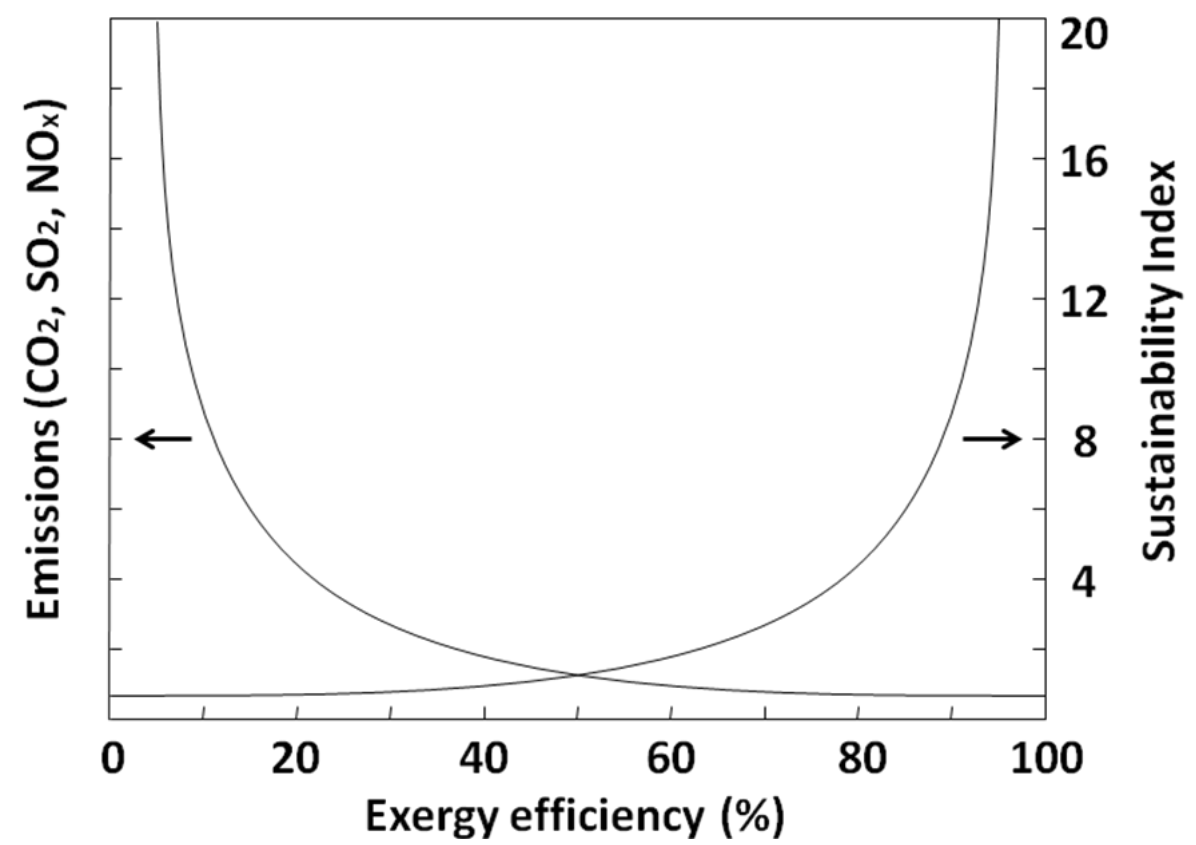

Figure 11. Relationship between the emissions and sustainability index (SI) of a typical process (Rosen et al., 2008)

\section{Exergy Efficiency}

As exergy has a triangle relationship with sustainability, energy, and environment as shown in Figure 10, exergy is best used to evaluate the energy quality of an energy/fuel resource, it at the same time can be used to help benefit the environment.

When exergy is used to evaluate the energy quality of a fuel resource, exergy efficiency can be used to assess the fuel convention and utilization processes. Figure 11 shows the relationship between the emissions and sustainability index (SI) of a typical process. To reduce the gaseous pollutants $\left(\mathrm{SO}_{x}, \mathrm{NO}_{x}, \mathrm{CO}, \mathrm{CH}_{4}\right.$, etc.) from a fuel convention or utilization process, one efficient alternative is to improve the process efficiency which is best evaluated by exergy efficiency (Rosen and Dincer, 2001; Kanoglu et al., 2009; Caliskan, 2014; Bilgen and Sarikaya, 2015). For a general fuel convention or utilization process, the best way to reduce the environmental impact and increase the fuel sustainability is to improve the exergy efficiency of the process (Figure 12) (Rosen and Dincer, 2001; Rosen et al., 2008; Kanoglu et al., 2009).

\section{CONCLUSIONS}

The sustainability of fuel is important for the sustainability triangle which mainly includes economic sustainability, environmental sustainability, and social sustainability, and it can be understood from a universal exergy basis: (a) higher chemical exergy of fuel, (b) lower chemical exergy of emissions, and (c) higher exergy efficiency of fuel conversion process. 


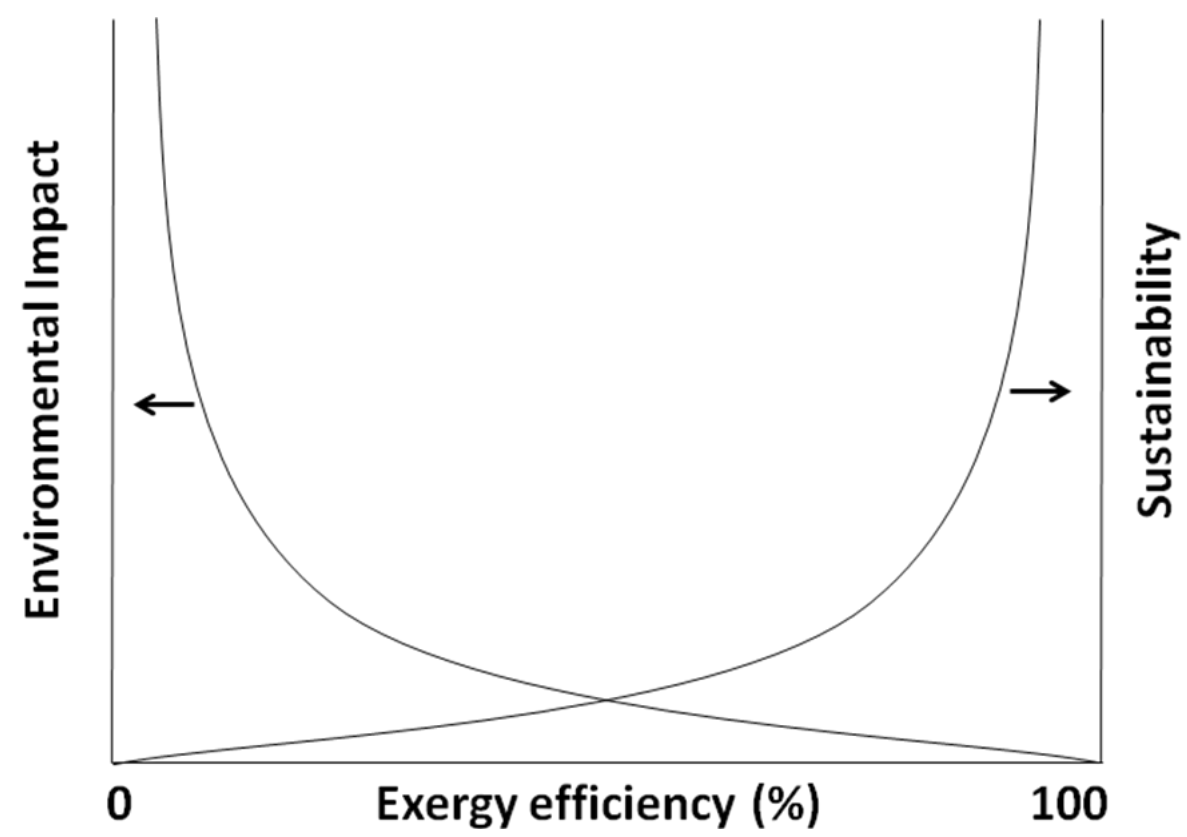

Figure 12. Relationship between the environmental impact and sustainability of a general fuel convention or utilization process (Rosen and Dincer, 2001; Rosen et al., 2008; Kanoglu et al., 2009)

\section{ACKNOWLEDGMENTS}

The financial supports from National Natural Science Foundation of China (No. 51606048), Harbin Science and Technology Research Funds for Innovative Talents (Grant No. RC2014QN008009), Fundamental Research Funds for the Central Universities (No. HIT.NSRIF.2015080), and China Scholarship Council (CSC: 201506125122) are acknowledged. The financial support from the Collaborative Innovation Center of Cleaner Coal Power Plant with Poly-generation is also acknowledged.

\section{REFERENCES}

Ao, Y., Gunnewiek, L. and Rosen, M. A. (2008). Critical Review of Exergy-Based Indicators for the Environmental Impact of Emissions. International Journal of Green Energy, 5(1-2), 87-104. https://doi.org/10.1080/15435070701839439

Atilgan, B. and Azapagic, A. (2015). Life cycle environmental impacts of electricity from fossil fuels in Turkey. Journal of Cleaner Production, 106, 555-564. https:// doi.org/10.1016/j.jclepro.2014.07.046

Bilgen, S. and Sarikaya, İ. (2015). Exergy for environment, ecology and sustainable development. Renewable and Sustainable Energy Reviews, 51, 1115-1131. https://doi.org/10.1016/j.rser.2015.07.015

Caliskan, H. (2014). Energy, exergy, thermoeconomic and sustainability analyses of a building heating system with a combi-boiler. International Journal of Exergy, 14(2), 244-273. https://doi.org/10.1504/IJEX.2014.060282

Caliskan, H. (2015). Novel approaches to exergy and economy based enhanced environmental analyses for energy systems. Energy Conversion and Management, 89, 156-161. https://doi.org/10.1016/j.enconman.2014.09.067

Chen, B., Chen, G. Q. and Yang, Z. F. (2006). Exergy-based resource accounting for China. Ecological Modelling, 196 (3-4), 313-328. https:// doi.org/10.1016/j.ecolmodel.2006.02.019

Chen, G. Q. and Chen, B. (2007). Resource analysis of the Chinese society 1980-2002 based on exergy-Part 1: Fossil fuels and energy minerals. Energy Policy, 35(4), 2038-2050. https://doi.org/10.1016/j.enpol.2006.06.009

Chen, G. Q. and Chen, B. (2009). Extended-exergy analysis of the Chinese society. Energy, 34(9), 1127-1144. https://doi.org/10.1016/j.energy.2009.04.023

Chen, B., Dai, J. and Sciubba, E. (2014). Ecological accounting for China based on extended exergy. Renewable and Sustainable Energy Reviews, 37, 334-347. https://doi.org/10.1016/j.rser.2014.05.022

Colombo, E., Rocco, M. V., Toro, C. and Sciubba, E. (2015). An exergy-based approach to the joint economic and environmental impact assessment of possible photovoltaic scenarios: A case study at a regional level in Italy. Ecological Modelling, 318, 64-74. https://doi.org/10.1016/j.ecolmodel.2014.11.006

Crane, P., Scott, D. S. and Rosen, M. A. (1992). Comparison of exergy of emissions from two energy conversion technologies. International Journal of Hydrogen Energy, 17(5), 345-350. https://doi.org/10.1016/03603199(92)90171-R 
Dai, J. and Chen, B. (2010). Extended exergy-based fossil fuels resource accounting in spatial distribution in 2007, China. Procedia Environmental Sciences, 2, 1799-1807. https://doi.org/10.1016/j.proenv.2010.10.191

Dai, J., Chen, B. and Sciubba, E. (2014). Extended exergy based ecological accounting for the transportation sector in China. Renewable and Sustainable Energy Reviews, 32, 229-237. https://doi.org/10.1016/j.rser.2014.01.001

Dincer, I. and Rosen, M. A. (1998). A worldwide perspective on energy, environment and sustainable development. International Journal of Energy Research, 22(15), 1305-1321. https://doi.org/10.1002/(SICI)1099114X(199812)22:15<1305::AID-ER417>3.0.CO;2-H

Dincer, I. (2000). Thermodynamics, exergy and environmental impact. Energy Source, 22, 723-732. https://doi.org/10.1080/00908310050120272

Dincer, I. (2002). On energetic, exergetic and environmental aspects of drying systems. International Journal of Energy Research, 26(8), 717-727. https://doi.org/10.1002/er.792

Dincer, I. and Rosen, M. A. (2005). Thermodynamic aspects of renewables and sustainable development. Renewable and Sustainable Energy Reviews, 9(2), 169-189. https://doi.org/10.1016/j.rser.2004.02.002

Dincer, I. (2007). Environmental and sustainability aspects of hydrogen and fuel cell systems. International Journal of Energy Research, 31(1), 29-55. https://doi.org/10.1002/er.1226

Dincer, I. and Naterer, G. F. (2010). Assessment of exergy efficiency and Sustainability Index of an air-water heat pump. International Journal of Exergy, 7(1), 37-50. https:// doi.org/10.1504/IJEX.2010.029613

EOLSS. (2002). Encyclopedia of Life Support Systems: Conceptual Framework, EOLSS Publishers. [online] Available at: http://www.eolss.com/eolss/cf.pdf (Accessed 07 May 2017).

FAO. (2017). [online] Available at: http://faostat3.fao.org/download/O/OA/E (Accessed 07 May 2017).

IUCN. (1980). International Union for Conservation of Nature and Natural Resources, ed., World Conservation Strategy: Living Resource Conservation for Sustainable Development, IUCN-UNEP-WWF.

Jahangir, S., Chen, B. and Wakeel, M. (2016). Extended exergy accounting for Karachi. Energy Procedia, 88, 52-57. https://doi.org/10.1016/j.egypro.2016.06.016

Jegannathan, K. R. and Nielsen, P. H. (2013). Environmental assessment of enzyme use in industrial productiona literature review. Journal of Cleaner Production, 42, 228-240. https://doi.org/10.1016/j.jclepro.2012.11.005

Jiang, M. M. and Chen, B. (2011). Integrated urban ecosystem evaluation and modeling based on embodied cosmic exergy. Ecological Modelling, 222(13), 2149-2165. https://doi.org/10.1016/j.ecolmodel.2011.04.012

Kanoglu, M., Dincer, I. and Cengel, Y. A. (2009). Exergy for better environment and sustainability. Environment, Development and Sustainability, 11, 971-988. https:// doi.org/10.1007/s10668-008-9162-3

Kirova-Yordanova, Z. (2010). Application of the exergy method to environmental impact estimation: The ammonium nitrate production as a case study. Energy, 35(8), 3221-3229. https://doi.org/10.1016/j.energy.2010.03.063

Koroneos, C. and Tsarouhis, M. (2012). Exergy analysis and life cycle assessment of solar heating and cooling systems in the building environment. Journal of Cleaner Production, 32, 52-60. https://doi.org/10.1016/j.jclepro.2012.03.012

Koroneos, C. J., Nanaki, E. A. and Xydis, G. A. (2012). Sustainability Indicators for the Use of Resources - The Exergy Approach. Sustainability, 4, 1867-1878. https://doi.org/10.3390/su4081867

Li, B., Wang, Q., Zhang, Y., Li, H., Gao, X. and Zhao, W. (2017). A new equation for estimating the exergy of woody biomass, 2nd Thermal and Fluid Engineering Conference (TFEC2017) and 4th International Workshop on Heat Transfer (IWHT2017), April 2-5, Las Vegas, USA.

Liu, Y. and Li, Y. (2015). An exergy-based evaluation model for the performance of the fossil fuel life cycle. International Journal of Exergy, 17(1), 92-109. https://doi.org/10.1504/IJEX.2015.069320

Midilli, A. and Dincer, I. (2010). Effects of some micro-level exergetic parameters of a PEMFC on the environment and sustainability. International Journal of Global Warming, 2(1), 65-80. https://doi.org/10.1504/IJGW.2010.032195

Romero, J. C. and Linares, P. (2014). Exergy as a global energy sustainability indicator. A review of the state of the art. Renewable and Sustainable Energy Reviews, 33, 427-442. https://doi.org/10.1016/j.rser.2014.02.012

Rosen, M. A. (2002). Assessing energy technologies and environmental impacts with the principles of thermodynamics. Applied Energy, 72, 427-441. https://doi.org/10.1016/S0306-2619(02)00004-1

Rosen, M. A. (2009a). Combating global warming via non-fossil fuel energy options. International Journal of Global Warming, 1(1-3), 2-28. https://doi.org/10.1504/IJGW.2009.027078

Rosen, M. A. (2009b). Energy Sustainability: A Pragmatic Approach and Illustrations. Sustainability, 1, 55-80. https:// doi.org/10.3390/su1010055

Rosen, M. A. (2017a). Sustainable Development: A Vital Quest. European Journal of Sustainable Development Research, 1(1), 2. https://doi.org/10.20897/ ejosdr.201702 
Rosen, M. A. (2017b). The Future of Sustainable Development: Welcome to the European Journal of Sustainable Development Research. European Journal of Sustainable Development Research, 1(1), 1. https://doi.org/10.20897/ ejosdr.201701

Rosen, M. A. and Dincer, I. (1997). On exergy and environmental impact. International Journal of Energy Research, 21(7), 643-654. https:// doi.org/10.1002/(SICI)1099-114X(19970610)21:7<643::AID-ER284>3.0.CO;2-I

Rosen, M. A. and Dincer, I. (1999). Exergy Analysis of Waste Emissions. International Journal of Energy Research, 23, 1153-1163. https:// doi.org/10.1002/(SICI)1099-114X(19991025)23:13<1153::AID-ER545>3.0.CO;2-Y

Rosen, M. A. and Dincer, I. (2001). Exergy as the confluence of energy, environment and sustainable development. International Journal of Exergy, 1(1), 3-13. https:// doi.org/10.1016/S1164-0235(01)00004-8

Rosen, M. A. and Dincer, I. (2003). Exergy-cost-energy-mass analysis of thermal systems and processes. Energy Conversion and Management, 44(10), 1633-1651. https:/ / doi.org/10.1016/S0196-8904(02)00179-6

Rosen, M. A., Dincer, I. and Kanoglu, M. (2008). Role of exergy in increasing efficiency and sustainability and reducing environmental impact. Energy Policy, 36, 128-137. https://doi.org/10.1016/j.enpol.2007.09.006

Sciubba, E. (2001). Beyond thermoeconomics? The concept of extended-exergy accounting and its application to the analysis and design of thermal systems. Exergy. An International Journal, 1(2), 68-84. https://doi.org/10.1016/S1164-0235(01)00012-7

Sciubba, E. (2003). Extended exergy accounting applied to energy recovery from waste: The concept of total recycling. Energy, 28(13), 1315-1334. https://doi.org/10.1016/S0360-5442(03)00111-7

Sciubba, E. and Wall, G. (2007). A brief commented history of exergy from the beginnings to 2004. International Journal of Thermophysics, 10, 1-26.

Sciubba, E. and Zullo, F. (2011). Is sustainability a thermodynamic concept? International Journal of Exergy, 8(1), 6885. https://doi.org/10.1504/IJEX.2011.037215

Sciubba, E. and Zullo, F. (2013). Stable and periodic solutions of an exergy-based model of population dynamics. Energy, 58, 202-209. https:// doi.org/10.1016/j.energy.2013.02.054

Statista. (2017). Statista: Global gross domestic product (GDP) 2020, [online] Available at: http://www.statista.com/statistics/268750/global-gross-domestic-product-gdp/ (Accessed 07 May 2017).

Statistical Review of World Energy. (2017). [online] Available at: http://www.bp.com/en/global/corporate/energy-economics/statistical-review-of-world-energy.html (Accessed 07 May 2017).

Stougie, L. and van der Kooi, H. J. (2012). Exergy and sustainability. International Journal of Exergy, 11(4), 508-517. https://doi.org/10.1504/IJEX.2012.050259

Szargut, J. (1980). International progress in second law analysis. Energy, 5(8-9), 709-718. https://doi.org/10.1016/0360-5442(80)90090-0

Szargut, J. (2005). Exergy method, technical and ecological applications, WIT Press, Boston, USA.

Szargut, J., Morris, D. and Steward, F. (1988). Energy analysis of thermal chemical, and metallurgical, processes, Hemisphere Publishing, New York, USA.

The World Bank. (2017). [online] Available at: http://data.worldbank.org/indicator/NY.GDP.MKTP.CD (Accessed 07 May 2017).

Ukidwe, N. U. and Bakshi, B. R. (2007). Industrial and ecological cumulative exergy consumption of the United States via the 1997 input-output benchmark model. Energy, 32(9), 1560-1592. https://doi.org/10.1016/j.energy.2006.11.005

Utlu, Z. and Hepbasli, A. (2004). Turkey's sectoral energy and exergy analysis between 1999 and 2000. International Journal of Energy Research, 28(13), 1177-1196. https:// doi.org/10.1002/er.1023

Wall, G., Sciubba, E. and Naso, V. (1994). Exergy use in the Italian society. Energy, 19(12), 1267-1274. https:// doi.org/10.1016/0360-5442(94)90030-2

Wall, G. and Gong, M. (2001). On exergy and sustainable development-Part 1: Conditions and concepts. International Journal of Exergy, 1(3), 128-145. https:/ / doi.org/10.1016/S1164-0235(01)00020-6

WCED. (1987). Our Common Future, World Commission on Environment and Development, Oxford University Press, New York, USA.

Whiting, K., Carmona, L. G. and Sousa, T. (2017). A review of the use of exergy to evaluate the sustainability of fossil fuels and non-fuel mineral depletion. Renewable and Sustainable Energy Revienss, 76, 202-211. https://doi.org/10.1016/j.rser.2017.03.059

Wikipedia. (2017). Wikipedia, the free encyclopedia. Sustainability, [online] Available at: https://en.wikipedia.org/wiki/Sustainability (Accessed 07 May 2017).

Wu, X. F., Chen, G. Q., Wu, X. D., Yang, Q., Alsaedi, A., Hayat, T. and Ahmad, B. (2015). Renewability and sustainability of biogas system: Cosmic exergy based assessment for a case in China. Renewable and Sustainable Energy Reviews, 51, 1509-1524. https://doi.org/10.1016/j.rser.2015.07.051 
Yang, J. and Chen, B. (2014). Extended exergy-based sustainability accounting of a household biogas project in rural China. Energy Policy, 68, 264-272. https:/ / doi.org/10.1016/j.enpol.2014.01.017

Zhang, Y., Ghaly, A. E. and Li, B. (2013). Determination of the exergy of four wheat straws. American Journal of Biochemistry and Biotechnology, 9(3), 338-347. https:// doi.org/10.3844/ajbbsp.2013.338.347

Zhang, Y., Gao, X., Li, B., Zhang, H., Qi, B. and Wu, Y. (2015 a). An expeditious methodology for estimating the exergy of woody biomass by means of heating values. Fuel, 159, 712-719. https://doi.org/10.1016/j.fuel.2015.06.102

Zhang, Y., Zhao, Y., Gao, X., Li, B. and Huang, J. (2015 b). Energy and exergy analyses of syngas produced from rice husk gasification in an entrained flow reactor. Journal of Cleaner Production, 95, 273-280. https://doi.org/10.1016/j.jclepro.2015.02.053

Zhang, Y., Yu, X., Li, B., Zhang, H., Liang, J. and Li, Y. (2016 a). Exergy characteristics of woody biomass. Energy Sources, Part A: Recovery, Utilization, and Environmental Effects, 38(16), 2438-2446. https://doi.org/10.1080/15567036.2015.1075088

Zhang, Y., Zhao, W., Li, B., Zhang, H., Jiang, B. and Ke, C. (2016b). Two equations for estimating the exergy of woody biomass based on the exergy values of ash contents. Energy, 106, 400-407. https://doi.org/10.1016/j.energy.2016.03.040

Zhang, Y., Fan, X., Li, B., Li, H. and Gao, X. (2017). Assessing the potential environmental impact of fuel using exergy-cases of wheat straw and coal. International Journal of Exergy, 23(1), 85-100. https://doi.org/10.1504/IJEX.2017.084517 